\title{
Relationship of residual feed intake and protein efficiency in lactating cows fed high- or low-protein diets
}

\author{
E. Liu $\left(\bullet\right.$ and M. J. VandeHaar ${ }^{1}$ () \\ Department of Animal Science, Michigan State University, East Lansing 48824
}

\begin{abstract}
Our objectives were to determine the repeatability of residual feed intake (RFI) across dietary protein levels and to determine the association between RFI and protein efficiency in lactating cows. Holstein cows ( $\mathrm{n}=166 ; 92$ primiparous, 74 multiparous) with initial milk yield $41.3 \pm 9.8 \mathrm{~kg} / \mathrm{d}$ were fed diets with high or low protein in peak lactation. Experiments were conducted as crossovers with 2 treatment periods of 28 to 35 d. Production of 69 of the 166 cows (42 primiparous, 27 multiparous) was also measured in late lactation. Low-protein diets were $14 \%$ crude protein $(\mathrm{CP})$ in peak lactation and $13 \% \mathrm{CP}$ in late lactation and were formulated to contain adequate rumen-degradable protein to maintain rumen function. High-protein diets were $18 \% \mathrm{CP}$ in peak lactation and $16 \% \mathrm{CP}$ in late lactation and contained extra expeller soybean meal to increase absorbed protein. Cows were milked twice daily; DMI and milk yield were recorded daily. Milk composition was measured over 4 consecutive milkings weekly, and body weight (BW) was measured 3 times weekly. Fixed effects of diet, parity, and treatment period, interaction of parity and diet, and random effects of experiment and cow nested within experiment were included in the model to compare intake and production performance between cows fed different levels of CP. The RFI value was calculated for each cow on each treatment based on the actual intake, milk energy output, metabolic BW, and body energy (calculated from BW change and body condition score over the treatment period) change. Ranking of cows for RFI was moderately repeatable across dietary protein in peak lactation $(\mathrm{r}=$ $0.59)$ but less repeatable in late lactation $(\mathrm{r}=0.41)$. Negative correlation was observed between RFI and protein efficiency values (dietary protein captured in milk) for cows in both peak lactation $(\mathrm{r}=-0.42)$ and late lactation $(\mathrm{r}=-0.24)$, which suggested that cows with higher energy efficiency had greater protein ef-
\end{abstract}

\footnotetext{
Received September 9, 2019.

Accepted December 13, 2019.

${ }^{1}$ Corresponding author: mikevh@msu.edu
}

ficiency. In conclusion, RFI was repeatable across dietary protein levels within lactation stage, and cows with lower RFI values utilized protein more efficiently. Key words: protein efficiency, residual feed intake

\section{INTRODUCTION}

Given that $40 \%$ of feed cost can be attributed to protein (St-Pierre, 2012), much effort has been made to improve protein efficiency in dairy cows. Many nutritional means have been explored to improve protein efficiency, such as altering protein sources, supplementing with non-protein nitrogen or specific amino acids, and lowering dietary protein levels (Sinclair et al., 2014; Broderick et al., 2015; Gidlund et al., 2015). However, the efficiency of converting feed protein to milk protein is still less than $30 \%$ in the modern dairy (Huhtanen and Hristov, 2009). We wondered whether genetic means could be used to further improve protein efficiency.

One possible way to enhance protein efficiency is to select cows based on residual feed intake (RFI). Calculated as the difference between actual feed intake and predicted feed intake, RFI is considered a direct measurement of energy efficiency (Koch et al., 1963) and has drawn considerable attention in the genetic improvement of dairy cattle (Connor, 2015; VandeHaar et al., 2016). The RFI takes into account all production variables and avoids bias caused by body size or milk production level when comparing efficiency between cows (Pryce et al., 2012; Connor, 2015). The RFI is usually calculated on an energy basis, and, although we expect that lower RFI would be associated with greater protein efficiency, this has not been demonstrated.

We also wondered whether RFI ranking among cows is repeatable across diets with varying protein levels. In lactating dairy cattle, RFI is repeatable across diets with varying starch and NDF contents (Potts et al., 2015; Carrasquillo-Mangual et al., 2016). However, no studies have reported the RFI ranking of cows across dietary protein levels. Most diets in previous RFI studies contained adequate or even excessive protein (Potts et al., 2015; Tempelman et al., 2015; Carrasquillo- 
Mangual et al., 2016). If RFI is not repeatable across protein levels, using the RFI information from cows fed excessive protein to determine protein efficiency might be misleading. Lack of repeatability might especially be a problem if cows are fed diets that limit protein to minimize nitrogen excretion. Thus, the objective of this study was to examine the repeatability of RFI across diets with high or marginally deficient protein levels and the relationship between RFI and protein efficiency. We hypothesized that (1) RFI was relatively repeatable across dietary protein levels, and (2) cows with lower RFI values would have higher protein efficiency.

\section{MATERIALS AND METHODS}

\section{Cows, Experimental Design, and Diets}

Experimental procedures were approved by the Institutional Animal Care and Use Committee of Michigan State University. Data from 166 cows in 11 separate crossover experiments, with 7 studies containing cows in peak lactation and 4 studies containing cows in late lactation, were used to determine the RFI and protein efficiency of individual cows across diets that were high $(\mathbf{H P})$ and low $(\mathbf{L P})$ in protein at different lactation stages. The LP diets were formulated to be marginally deficient in protein so that milk production would likely drop.

In the 7 experiments containing 166 peak-lactation cows, all cows were 50 to 130 DIM at the beginning of each experiment. For all 7 experiments, the 2 experimental periods lasted 28 to $35 \mathrm{~d}$ per period. Within each experiment, cows were blocked based on their parity and productivity (milk energy per unit of metabolic BW) and then randomly assigned to 1 of the 2 treatment sequences (HP-LP, or LP-HP). For cows in peak lactation the LP diets $\left(\mathbf{L P}_{\text {peak }}\right)$ contained $31 \% \mathrm{NDF}$, $32 \%$ starch, and $14 \% \mathrm{CP}$, and the HP diets $\left(\mathbf{H P}_{\text {peak }}\right)$ contained 29\% NDF, 30\% starch, and 18\% CP. Both diets contained at least $9.8 \% \mathrm{RDP}$ (DM basis) to maintain adequate rumen function (NRC, 2001). The extra protein of $\mathrm{HP}_{\text {peak }}$ was achieved by replacing soybean hulls and ground corn with expeller soybean meal (Table 1).

In the 4 experiments containing 69 late-lactation cows, DIM was 190 to $250 \mathrm{~d}$ at the beginning of each experiment. Intake, BW, and milk production of the 69 cows were measured in both peak and late lactation. For all the 4 experiments, the 2 experimental periods lasted 28 to $35 \mathrm{~d}$ per period. Within each experiment, cows were blocked based on their parity and milk energy per unit of metabolic BW, and then randomly assigned to 1 of the 2 treatment sequences (HP-LP, or LP-HP). For cows in late lactation, the LP diets
$\left(\mathbf{L P}_{\text {late }}\right)$ contained $40 \% \mathrm{NDF}, 26 \%$ starch, and $13 \% \mathrm{CP}$, and the HP diets $\left(\mathbf{H P}_{\text {late }}\right)$ contained $38 \%$ NDF, $24 \%$ starch, and $16 \% \mathrm{CP}$. Both diets contained at least 9.0\% RDP (DM basis) for rumen function. The extra protein of $\mathrm{HP}_{\text {late }}$ was achieved by replacing soybean hulls and ground corn with expeller soybean meal (Table 1).

All cows were housed in individual tiestalls and milked twice a day (0430 and $1530 \mathrm{~h}$ ). Tiestalls were equipped with a double-cupped watering system to prevent contamination of feed with water and with side panels and a front gate to prevent other cows from stealing feed during cow movements. Water was available ad libitum. Cows were fed once a day $(1200 \mathrm{~h})$ at $>110 \%$ of expected intake based on intake of the previous day, and orts were removed $(1000 \mathrm{~h})$ and weighed before feeding. Milk yield was recorded electronically at each milking, and milk samples were obtained from 4 consecutive milkings each week. Milk samples were analyzed for fat, protein, lactose, SCC, and MUN with infrared spectroscopy (AOAC, 1990; method 972.160) by Michigan DHIA (Grand Ledge, MI). Body weight for each cow was recorded 3 times per week, immediately after afternoon milking. At the beginning and end of each period, BCS was determined by 3 trained investigators and averaged for each cow on a 5-point scale, where $1=$ thin and $5=$ fat (Wildman et al., 1982).

Collection and analyses of diet ingredients were the same for all the experiments. During the last $5 \mathrm{~d}$ of experimental periods, samples of feed ingredients were obtained daily to determine the nutrient profile of the diets. All samples were frozen after collection until analysis. Samples were composited to obtain 1 sample per period and dried in a forced-air oven $\left(57^{\circ} \mathrm{C}\right.$ for $>72$ h) before grinding through a Wiley mill $(5-\mathrm{mm}$ and 1-mm screens; Arthur H. Thomas Co., Philadelphia, PA). Samples of feed were analyzed for CP, starch, NDF, and ether extract.

\section{Calculations}

Milk energy output (MilkE, Mcal/d) for individual cows was estimated using the following equation (NRC, 2001, Equation 2-15):

$$
\begin{aligned}
\text { MilkE }=[9.29 & \times \text { fat }(\mathrm{kg})+5.63 \times \text { true protein }(\mathrm{kg}) \\
& +3.95 \times \text { lactose }(\mathrm{kg})]
\end{aligned}
$$

where each component was calculated as the average output of individual cows during the treatment period.

The milk-to-feed ratio for a cow during a period was determined as the average daily ECM yield [ECM = $0.327 \times$ milk $(\mathrm{kg})+12.95 \times$ fat $(\mathrm{kg})+7.20 \times$ protein 
(kg); Tyrrell and Reid, 1965] divided by the average daily DMI over the entire period.

For cows more than $190 \mathrm{~d}$ pregnant, BW was corrected for conceptus weight for use in the RFI equation and to calculate energy and protein change of body tissues. Conceptus weight $(\mathrm{CW})$ was calculated using the following equation from NRC (2001):

$$
\mathrm{CW}=[18+(\mathrm{D}-190) \times 0.665] \times(\mathrm{CBW} / 45),
$$

where D was the day of gestation between 190 and 279, and $\mathrm{CBW}$ was the calf birth weight.

Metabolic BW (MBW) of a cow was estimated as $\mathrm{BW}^{0.75}$, where $\mathrm{BW}$ was the mean measured $\mathrm{BW}$ for the cow during the treatment period.

Mean daily BW change $(\boldsymbol{\Delta B W}, \mathrm{kg} / \mathrm{d})$ was calculated for each cow within the treatment period by linear regression after 2 rounds of removing outliers in the data. An outlier was any BW >3.5 standard deviations (SD) from the regression line.
Energy expended for body tissue gain $(\boldsymbol{\Delta B o d y} \mathbf{E}$, $\mathrm{Mcal} / \mathrm{d}$ ) was estimated using an equation derived from NRC (2001, Table 2-5):

$$
\Delta \mathrm{Body} \mathrm{E}=(2.88+1.036 \times \mathrm{BCS}) \times \Delta \mathrm{BW},
$$

where BCS was the average BCS for a cow during the treatment period.

Energy expended for pregnancy (PregE, Mcal/d) was estimated using the following equation from NRC (2001, Equation 2-19):

$$
\begin{aligned}
\text { PregE } & =[(0.00318 \times \mathrm{D}-0.0352) \\
& \times(\mathrm{CBW} / 45)] / 0.218,
\end{aligned}
$$

where D was the day of gestation between 190 and 279, and CBW was the calf birth weight.

\begin{tabular}{|c|c|c|c|c|}
\hline \multirow[b]{3}{*}{ Item } & \multicolumn{4}{|c|}{ Treatment } \\
\hline & \multicolumn{2}{|c|}{ Peak lactation } & \multicolumn{2}{|c|}{ Late lactation } \\
\hline & $\mathrm{HP}_{\text {peak }}$ & $\mathrm{LP}_{\text {peak }}$ & $\mathrm{HP}_{\text {late }}$ & $\mathrm{LP}_{\text {late }}$ \\
\hline \multicolumn{5}{|l|}{ Ingredient, \% DM } \\
\hline Corn silage & 35.2 & 35.2 & 50.0 & 50.0 \\
\hline Alfalfa silage & 15.7 & 15.7 & 18.2 & 18.2 \\
\hline Corn grain, ground & 25.6 & 29.7 & 8.2 & 11.4 \\
\hline Soybean hulls & 5.7 & 12.8 & 9.2 & 15.8 \\
\hline Soybean meal solvent extracted $48 \% \mathrm{CP}$ & 0.3 & 2.5 & 0.6 & 0.4 \\
\hline Expeller soybean meal ${ }^{4}$ & 13.4 & - & 9.7 & - \\
\hline Vitamin and mineral mix $^{2}$ & 3.2 & 3.2 & 3.3 & 3.3 \\
\hline Urea & 0.9 & 0.9 & 1.0 & 1.0 \\
\hline Forage:concentrate & $51: 49$ & $51: 49$ & $68: 32$ & $68: 32$ \\
\hline \multicolumn{5}{|l|}{ Nutrient composition, \% DM } \\
\hline $\mathrm{DM}$ & 47.1 & 47.1 & 37.9 & 37.9 \\
\hline $\mathrm{NDF}$ & 29.4 & 31.3 & 38.0 & 40.2 \\
\hline Forage NDF & 20.7 & 20.7 & 29.5 & 29.5 \\
\hline Starch & 31.5 & 33.5 & 24.4 & 26.0 \\
\hline $\mathrm{CP}$ & 18.0 & 14.3 & 15.9 & 12.8 \\
\hline RDP & 10.3 & 9.8 & 10.0 & 9.0 \\
\hline RUP & 7.7 & 4.5 & 6.0 & 3.5 \\
\hline Apparent $\mathrm{NE}_{1},{ }^{3} \mathrm{Mcal} / \mathrm{kg}$ & 1.7 & 1.6 & 1.5 & 1.6 \\
\hline \multicolumn{5}{|c|}{$\begin{array}{l}{ }^{1} \mathrm{HP}_{\text {peak }} \text { and } \mathrm{LP}_{\text {peak }} \text { were high- and low-protein diets fed to peak-lactation cows, and } \mathrm{HP}_{\text {late }} \text { and } \mathrm{LP}_{\text {late }} \text { were } \\
\text { high- and low-protein diets fed to late-lactation cows. Experimental diets were fed to cows in crossover design } \\
\text { with at least } 28 \text {-d periods. }\end{array}$} \\
\hline \multicolumn{5}{|c|}{$\begin{array}{l}{ }^{2} \text { Vitamin and mineral mix contained } 24.8 \% \text { ground corn grain, } 21.5 \% \text { dehydrated cane molasses, } 11.2 \% \\
\text { limestone, } 9.6 \% \text { blood meal, } 9.0 \% \text { sodium bicarbonate, } 6.6 \% \text { dicalcium phosphate, } 4.2 \% \text { ReaShure Choline } \\
\text { (Balchem Corp., New Hampton, NY), 3.1\% magnesium sulfate, } 2.8 \% \text { salt, } 2.0 \% \text { vegetable oil, } 1.5 \% \text { niacin, } 1.3 \% \\
\text { trace mineral mix, 0.95\% biotin, } 0.7 \% \text { Yeast Plus (Chr. Hansen, Milwaukee, WI), } 0.54 \% \text { vitamin ADE premix, } \\
0.32 \% \text { selenium yeast, and } 0.09 \% \text { Rumensin } 90 \text { (Elanco, Animal Health, Indianapolis, IN). }\end{array}$} \\
\hline \multicolumn{5}{|c|}{$\begin{array}{l}{ }^{3} \text { Mean apparent net energy concentration of diets }\left(\mathrm{Diet} \mathrm{NE}_{\mathrm{L}}\right) \text {, based on average cow performance. For each } \\
\text { diet, DietNE } \mathrm{L}_{\mathrm{L}}=\text { the average of (MilkE }+0.08 \times \mathrm{MBW}+\Delta \text { BodyE)/DMI for all cows on the diet, where MilkE } \\
\text { is net energy utilized for milk synthesis, MBW is metabolic body weight, and } \Delta \text { BodyE is net energy captured } \\
\text { in body tissue. }\end{array}$} \\
\hline
\end{tabular}

Apparent diet energy content $\left(\right.$ DietNE $_{\mathrm{L}}, \mathrm{Mcal} / \mathrm{kg}$ ) was calculated for each diet as the average $\mathrm{NE}_{\mathrm{L}}$ re-

Table 1. Feed ingredients and nutrient composition of experimental $\operatorname{diets}^{1}$ 
quired by each cow divided by her average daily intake for the diet:

$$
\begin{gathered}
\operatorname{DietNE}_{\mathrm{L}}=\text { Average }[(\text { MilkE }+0.08 \times \mathrm{MBW} \\
+\Delta \text { BodyE }+ \text { PregE }) / \mathrm{DMI}]
\end{gathered}
$$

where DMI was the average DMI for a cow during the treatment period.

\section{Models and Statistics}

The RFI for each cow on each diet was calculated as the residual term in the prediction of DMI. The DMI for an individual cow during each period was regressed as a function of major energy sinks using the GLM Procedure in SAS (version 9.4; SAS Institute Inc., Cary, $\mathrm{NC}$ ). To define RFI for cows in peak lactation, DMI was modeled as follows:

$$
\begin{gathered}
\mathrm{DMI}=\beta_{0}+\beta_{1} \times \text { MilkE }+\beta_{2} \times \mathrm{MBW} \\
+\beta_{3} \times \Delta \text { BodyE }+\beta_{4} \times \mathrm{DIM}+\beta_{5} \times \mathrm{DIM} \\
\times \mathrm{DIM}+\beta_{6} \times \mathrm{BCS}+\text { Parity } \\
+ \text { Experiment }+ \text { Cohort }(\text { Experiment }) \\
+\operatorname{Diet}(\text { Cohort } \times \text { Experiment })+e
\end{gathered}
$$

where DMI was the observed DMI, MilkE was the observed milk energy output, MBW was the average $\mathrm{BW}^{0.75}, \Delta \mathrm{BodyE}$ was the predicted change in body energy based on measured BW and BCS, DIM was the average DIM during each treatment period, and BCS was the average BCS during each treatment period. Parity (1 or $2+)$, experiment (1 through 7$)$, cohort nested within experiment, and diet nested within cohort and experiment were fixed effects, where a cohort is a group of cows that ate the same diet at the same time. The RFI was defined as the residual term $(e)$ in the model.

For cows in late lactation, DMI was modeled as follows:

$$
\begin{gathered}
\text { DMI }=\beta_{0}+\beta_{1} \times \text { MilkE }+\beta_{2} \times \mathrm{MBW} \\
+\beta_{3} \times \Delta \text { BodyE }+\beta_{4} \times \text { PregE }+\beta_{5} \times \mathrm{DIM} \\
+\beta_{6} \times \text { BCS }+ \text { Parity }+ \text { Experiment } \\
\quad+\text { Cohort }(\text { Experiment }) \\
+\operatorname{Diet}(\text { Cohort } \times \text { Experiment })+e
\end{gathered}
$$

where PregE was the energy expended for pregnancy, and RFI remained the residual term $(e)$ in the model.
To determine the number of animals that changed their efficiency classification when they were switched from one diet to the other, cows were grouped into high- (HRFI), medium- (MRFI), and low- (LRFI) RFI groups. Cows $>0.5 \mathrm{SD}$ of the mean RFI for a cohort were classified as HRFI, cows $<-0.5 \mathrm{SD}$ were classified as LRFI, and those $\pm 0.5 \mathrm{SD}$ were classified as MRFI.

Repeatability of RFI across dietary protein levels was calculated using Pearson correlation coefficients in the CORR procedure of SAS. Two RFI values within each lactation stage for each cow $\left(\mathrm{RFI}_{\mathrm{HP} \text { peak }}\right.$ vs. $\mathrm{RFI}_{\mathrm{LPpeak}}$; $\mathrm{RFI}_{\mathrm{HPlate}} \mathrm{vs.} \mathrm{RFI}_{\text {LPlate }}$ ) were included in the analyses. To examine the RFI repeatability across lactation stages, 2 RFI values were calculated: $\mathbf{R F I}_{\text {peak }}$ and $\mathbf{R F I}_{\text {late }}$, where $\mathrm{RFI}_{\text {peak }}$ was the average RFI across diets in peak lactation, and $\mathrm{RFI}_{\text {late }}$ was the average RFI across diets in late lactation. Pearson correlation coefficients for $\mathrm{RFI}_{\text {peak }}$ and $\mathrm{RFI}_{\text {late }}$ were calculated. To further examine the RFI repeatability across dietary protein levels, 2 RFI values were calculated: $\mathbf{R F I}_{\text {high }}$ and $\mathbf{R F I}_{\text {low }}$, where $\mathrm{RFI}_{\text {high }}$ was the average RFI for high-protein diets across lactation stage, and $\mathrm{RFI}_{\text {low }}$ was the average $\mathrm{RFI}$ for low-protein diets across lactation stage. Pearson correlation coefficients for $\mathrm{RFI}_{\text {high }}$ and $\mathrm{RFI}_{\text {low }}$ were calculated. Correlation was considered as significant at $P$ $\leq 0.05$, and trends were designated at $P \leq 0.10$.

For each cow in each diet, protein efficiency was calculated as dietary protein captured in milk protein (milk protein efficiency, MPE), and dietary protein captured in milk protein and body tissues (gross protein efficiency, GPE), respectively. Protein captured for body tissue gain (BodyPro, $\mathrm{kg} / \mathrm{d}$ ) was calculated using the following equations, which were derived as averages for BCS of 3.0 based on NRC (2001):

$$
\begin{aligned}
& \text { BodyPro }=0.12 \times \Delta \mathrm{BW} \text { for primiparous cows; } \\
& \text { BodyPro }=0.07 \times \Delta \mathrm{BW} \text { for multiparous cows }
\end{aligned}
$$

To quantify the association among RFI, MPE, and GPE, Pearson correlation coefficients were obtained using the CORR procedure in SAS. Partial correlations accounting for effects of parity, cohort, and experiment were estimated using the PARTIAL option in the CORR procedure. To further determine the differences in protein efficiency between the most and least efficient cows, cows with different RFI for each diet (HP or LP) in each lactation stage across all 11 experiments were compared. The effect of RFI was determined using the GLM procedure of SAS, according to the model $\mathrm{Y}_{\mathrm{i}}$ $=\mu+\mathrm{R}_{\mathrm{i}}+e$, where $\mathrm{Y}_{\mathrm{i}}$ is the dependent variable, $\mu$ was the overall mean, $R_{i}$ was the fixed effect of RFI group, and $e$ was the residual error. 
Production, efficiency, and energy partitioning responses to diets with each lactation stage were analyzed using the MIXED procedure in SAS, with fixed effects of diet, parity, and period, interaction of parity and diet, and the random effects of experiment and cow nested within experiment. Significance was considered at $P \leq 0.05$ and tendency at $P \leq 0.10$. Interactions were considered significant at $P \leq 0.10$ and trends at $P \leq 0.15$.

\section{RESULTS}

\section{Animal Performance}

Cows fed low protein, in general, ate less, produced less milk, and gained less BW than cows fed high protein, in both peak and late lactations. As shown in Tables 2 and $3, \mathrm{LP}_{\text {peak }}$ decreased DMI $(P<0.01)$, milk yield $(P<0.01)$, milk fat yield $(P<0.01)$, milk protein yield $(P<0.01)$, milk lactose yield $(P<0.01)$, milk protein percentage $(P<0.01)$, milk lactose percentage $(P<0.01)$, and MUN $(P<0.01)$. For these cows, $\mathrm{LP}_{\text {peak }}$ also decreased BW $(P<0.01)$, BW gain $(P<0.01)$, BCS $(P=0.04)$, and change in BCS $(P=$ 0.06). In peak lactation, $\mathrm{LP}_{\text {peak }}$ also decreased $\mathrm{ECM}$ per kilogram of DMI $(P<0.01)$, milk energy $(P<0.01)$, and estimated retained energy $(P<0.01)$. As shown in Tables 4 and $5, \mathrm{LP}_{\text {late }}$ decreased DMI $(P<0.01)$, milk yield $(P<0.01), 3.5 \%$ FCM $(P<0.01)$, milk fat yield
$(P<0.01)$, milk protein yield $(P<0.01)$, milk lactose yield $(P<0.01)$, and MUN $(P<0.01)$. For these cows, $\mathrm{LP}_{\text {late }}$ also decreased BW $(P<0.01)$, non-pregnant BW $(P<0.01)$, BW gain $(P<0.01)$, non-pregnant BW gain $(P<0.01)$, and BCS $(P=0.04)$. We further found that $\mathrm{LP}_{\text {late }}$ also decreased ECM per kilogram of DMI $(P<0.01)$, milk energy $(P<0.01)$, maintenance energy $(P<0.01)$, and estimated retained energy $(P$ $<0.01)$.

Primiparous cows in general ate less and produced less milk but with greater milk component concentration, in both peak and late lactations. As shown in Tables 2 and 3, among peak-lactation cows, compared with multiparous cows, primiparous cows had lower DMI $(P$ $<0.01)$, milk yield $(P<0.01)$, FCM $(P<0.01)$, milk fat yield $(P<0.01)$, milk protein yield $(P<0.01)$, MUN $(P<0.01)$, and milk lactose yield $(P<0.01)$, with higher milk protein percentage $(P=0.05)$ and milk lactose percentage $(P<0.01)$. Primiparous cows also had less milk energy $(P<0.01)$ and maintenance energy $(P<0.01)$ compared with multiparous cows. As shown in Tables 4 and 5, among all late-lactation cows, compared with multiparous cows, primiparous cows had higher milk fat yield $(P=0.08)$, milk fat percentage $(P=0.02)$, and milk lactose percentage $(P$ $<0.01)$. Primiparous cows also had lower BW $(P<$ $0.01)$, non-pregnant BW $(P<0.01)$, BCS $(P<0.01)$, change in $\mathrm{BW}(P=0.07)$, and maintenance energy $(P$ $<0.01)$ compared with multiparous cows.

Table 2. Dry matter intake, milk production, milk components, and feed efficiency for cows fed experimental diets in peak lactation ${ }^{1}$

\begin{tabular}{|c|c|c|c|c|c|c|c|c|c|}
\hline \multirow[b]{2}{*}{ Item } & \multicolumn{2}{|c|}{ Treatment $^{2}$} & \multirow[b]{2}{*}{ SEM } & \multicolumn{2}{|c|}{ Parity $^{3}$} & \multirow[b]{2}{*}{ SEM } & \multicolumn{3}{|c|}{$P$-value ${ }^{4}$} \\
\hline & $\begin{array}{c}\mathrm{HP}_{\text {peak }} \\
\mathrm{n}=166\end{array}$ & $\begin{array}{c}\mathrm{LP}_{\text {peak }} \\
\mathrm{n}=166\end{array}$ & & $\begin{array}{c}\text { Primi. } \\
\mathrm{n}=184\end{array}$ & $\begin{array}{c}\text { Multi. } \\
\mathrm{n}=148\end{array}$ & & TRT & Parity & TRT $\times$ parity $^{5}$ \\
\hline DMI, $\mathrm{kg} / \mathrm{d}$ & 24.3 & 23.3 & 0.14 & 21.3 & 26.3 & 0.35 & $<0.01$ & $<0.01$ & 0.86 \\
\hline \multicolumn{10}{|l|}{ Milk yield, $\mathrm{kg} / \mathrm{d}$} \\
\hline Milk & 41.2 & 37.3 & 0.23 & 33.7 & 44.7 & 0.96 & $<0.01$ & $<0.01$ & 0.01 \\
\hline $\mathrm{ECM}^{6}$ & 41.0 & 37.2 & 0.53 & 34.8 & 43.3 & 0.87 & $<0.01$ & $<0.01$ & 0.19 \\
\hline Fat, $\mathrm{kg} / \mathrm{d}$ & 1.41 & 1.27 & 0.01 & 1.18 & 1.50 & 0.03 & $<0.01$ & $<0.01$ & 0.59 \\
\hline Fat, $\%$ & 3.46 & 3.49 & 0.02 & 3.53 & 3.43 & 0.06 & 0.13 & 0.13 & 0.30 \\
\hline Protein, kg/d & 1.21 & 1.07 & 0.01 & 1.01 & 1.28 & 0.02 & $<0.01$ & $<0.01$ & 0.18 \\
\hline Protein, \% & 2.97 & 2.94 & 0.01 & 2.99 & 2.91 & 0.03 & $<0.01$ & 0.05 & 0.07 \\
\hline Lactose, kg/d & 2.07 & 1.84 & 0.01 & 1.71 & 2.20 & 0.05 & $<0.01$ & $<0.01$ & 0.01 \\
\hline Lactose, $\%$ & 5.01 & 4.99 & 0.01 & 5.07 & 4.94 & 0.02 & 0.01 & $<0.01$ & 0.14 \\
\hline MUN, mg/dL & 15.1 & 9.2 & 0.13 & 11.6 & 12.7 & 0.20 & $<0.01$ & $<0.01$ & 0.16 \\
\hline
\end{tabular}

\footnotetext{
${ }^{1}$ Average DIM was 125 for primiparous cows in $\mathrm{HP}_{\text {peak }}$ diets, 126 for primiparous cows in $\mathrm{LP}_{\text {peak }}$ diets, 122 for multiparous cows in $\mathrm{HP}_{\text {peak }}$ diets, and 121 for multiparous cows in $\mathrm{LP}_{\text {peak }}$ diets. Average parity for multiparous cows was 2.94 in peak lactation.

${ }^{2}$ Treatments contained $18 \% \mathrm{CP}\left(\mathrm{HP}_{\text {peak }}\right)$ and $14 \% \mathrm{CP}\left(\mathrm{LP}_{\text {peak }}\right)$ on a DM basis for peak-lactation cows.

${ }^{3}$ Primi. $=$ primiparous cows; multi. $=$ multiparous cows.

${ }^{4} P$-value associated with treatment differences $\left(\mathrm{HP}_{\text {peak }}\right.$ vs. $\left.\mathrm{LP}_{\text {peak }} ; \mathrm{TRT}\right)$ and parity differences (primi. vs. multi.; parity) in peak-lactation cows.

${ }^{5}$ Values within each TRT $\times$ parity interaction are shown in Supplemental Table S1 (https://doi.org/10.3168/jds.2019-17567).

${ }^{6} \mathrm{ECM}=[(0.327 \times \mathrm{kg}$ of milk $)+(12.95 \times \mathrm{kg}$ of milk fat $)+(7.20 \times \mathrm{kg}$ of milk protein $)] ;$ Tyrrell and Reid (1965).

${ }^{7} 3.5 \% \mathrm{FCM}=[(0.4324 \times \mathrm{kg}$ of milk $)+(16.216 \times \mathrm{kg}$ of milk fat $)]$.
} 
Table 3. Body weight, body condition score, and calculated energy values for cows fed experimental diets in peak lactation

\begin{tabular}{|c|c|c|c|c|c|c|c|c|c|}
\hline Item & \multicolumn{2}{|c|}{ Treatment $^{1}$} & SEM & \multicolumn{2}{|c|}{ Parity $^{2}$} & SEM & \multicolumn{3}{|c|}{$P$-value ${ }^{3}$} \\
\hline BCS, unit & 3.23 & 3.19 & 0.02 & 3.23 & 3.20 & 0.05 & 0.04 & 0.41 & 0.54 \\
\hline Change in $\mathrm{BW},{ }^{4} \mathrm{~kg} / \mathrm{d}$ & 0.57 & 0.20 & 0.10 & 0.38 & 0.40 & 0.10 & $<0.01$ & 0.88 & 0.23 \\
\hline Change in BCS, unit/28 d & 0.07 & 0.02 & 0.03 & 0.04 & 0.05 & 0.03 & 0.06 & 0.83 & 0.10 \\
\hline Apparent $\mathrm{NE}_{\mathrm{L}}, \mathrm{Mcal} / \mathrm{d}$ & 42.1 & 36.7 & 0.03 & 35.4 & 43.4 & 0.03 & $<0.01$ & $<0.01$ & 0.51 \\
\hline Milk, Mcal/d & 28.1 & 25.1 & 0.18 & 23.4 & 29.9 & 0.57 & $<0.01$ & $<0.01$ & 0.15 \\
\hline Body tissue gain, Mcal/d & 3.64 & 1.26 & 0.63 & 2.38 & 2.52 & 0.66 & $<0.01$ & 0.82 & 0.30 \\
\hline Maintenance, Mcal/d & 10.4 & 10.3 & 0.01 & 9.6 & 11.0 & 0.10 & $<0.01$ & $<0.01$ & 0.10 \\
\hline
\end{tabular}

${ }^{1}$ Treatments contained $18 \% \mathrm{CP}\left(\mathrm{HP}_{\text {peak }}\right)$ and $14 \% \mathrm{CP}\left(\mathrm{LP}_{\text {peak }}\right)$ on a $\mathrm{DM}$ basis for peak-lactation cows.

${ }^{2}$ Primi. = primiparous cows; multi. = multiparous cows.

${ }^{3} P$-value associated with treatment differences ( $\mathrm{HP}_{\text {peak }}$ vs. $\mathrm{LP}_{\text {peak }}$; TRT) and parity differences (primi vs. multi.; parity) in peak-lactation cows. ${ }^{4}$ Determined by linear regression using BW measurements throughout the period.

${ }^{5}$ Milk $($ MilkE $)=[9.29 \times$ fat $(\mathrm{kg})+5.63 \times$ true protein $(\mathrm{kg})+3.95 \times$ lactose $(\mathrm{kg})]$. Body tissue gain $(\Delta$ BodyE $)=[(2.88+1.036 \times \mathrm{BCS}) \times$ $\Delta \mathrm{BW}] ;$ maintenance $=0.08 \times \mathrm{MBW}$, where $\mathrm{MBW}=$ metabolic body weight, $\mathrm{BW}^{0.75}$.

\section{Repeatability of RFI Across Dietary Protein Levels and Lactation Stages}

In the RFI model among peak-lactation cows, the coefficients for the major energy sinks were $0.44(P<$ $0.01)$ for MilkE, $0.06(P<0.01)$ for MBW, and 0.03 $(P=0.03)$ for $\triangle$ BodyE. The model coefficient of determination $\left(\mathrm{R}^{2}\right)$ and root mean square error were 0.87 and 1.50 , respectively. In the RFI model among late- lactation cows, the coefficients for the major energy sinks were $0.37(P<0.01)$ for MilkE, $0.08(P<0.01)$ for MBW, $0.05(P=0.13)$ for $\triangle$ BodyE, and $-0.04(P$ $=0.83)$ for PregE. The model $\mathrm{R}^{2}$ and root mean square error were 0.80 and 1.31, respectively. Further details are shown in Table 6.

Regarding RFI repeatability, in general, cows with lower RFI values when fed HP diets still had low RFI when switched to LP diets. In peak lactation, RFI was

Table 4. Dry matter intake, milk production, milk components and feed efficiency for cows fed experimental diets in late lactation ${ }^{1}$

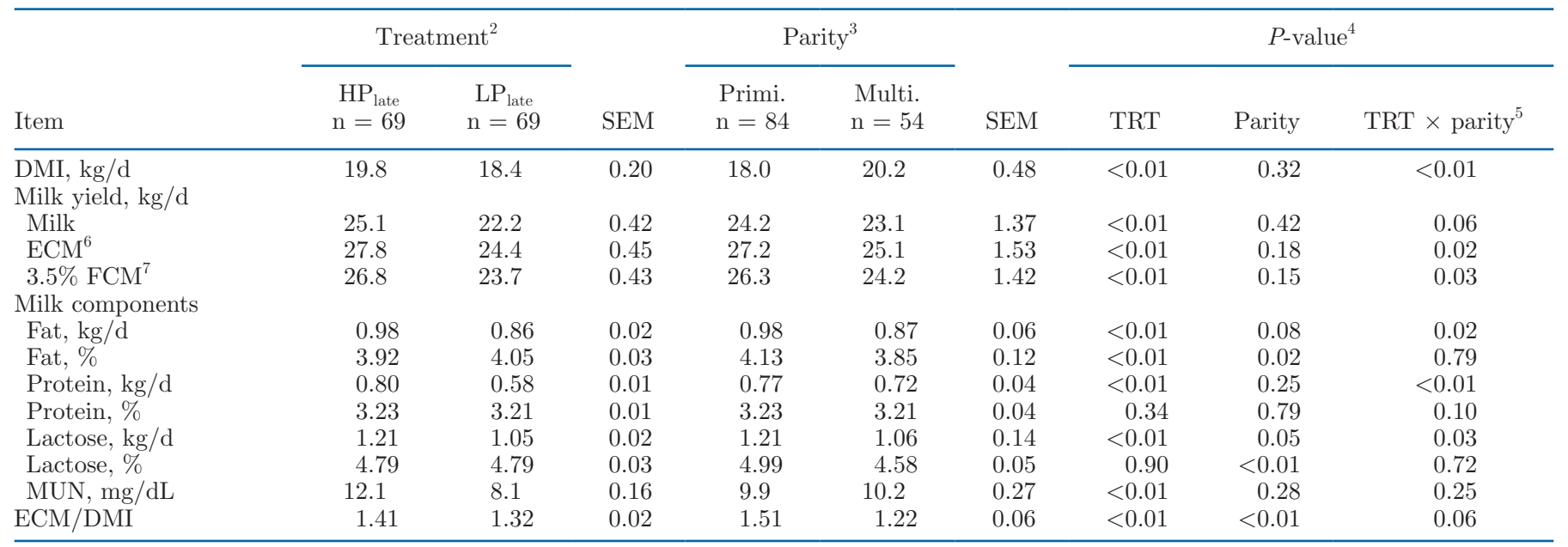

${ }^{1}$ Average DIM was 258 for primiparous cows in $\mathrm{HP}_{\text {late }}$ diets, 257 for primiparous cows in $\mathrm{LP}_{\text {late }}$ diets, 263 for multiparous cows in $\mathrm{HP}_{\text {late }}$ diets, and 264 for multiparous cows in $\mathrm{LP}_{\text {late }}$ diets. Average parity for multiparous cows was 3.12 in late lactation.

${ }^{2}$ Treatments contained $16 \% \mathrm{CP}\left(\mathrm{HP}_{\text {late }}\right)$ and $13 \% \mathrm{CP}\left(\mathrm{LP}_{\text {late }}\right)$ on a $\mathrm{DM}$ basis for late-lactation cows.

${ }^{3}$ Primi. $=$ primiparous cows; multi. $=$ multiparous cows.

${ }^{4} P$-value associated with treatment differences $\left(\mathrm{HP}_{\text {late }}\right.$ vs. $\mathrm{LP}_{\text {late }}$; TRT) and parity differences (primi vs. multi.; parity) in late-lactation cows.

${ }^{5}$ Values within each TRT $\times$ parity interaction are shown in Supplemental Table S1 (https://doi.org/10.3168/jds.2019-17567).

${ }^{6} \mathrm{ECM}=[(0.327 \times \mathrm{kg}$ of milk $)+(12.95 \times \mathrm{kg}$ of milk fat $)+(7.20 \times \mathrm{kg}$ of milk protein $)] ;$ Tyrrell and Reid (1965).

${ }^{7} 3.5 \% \mathrm{FCM}=[(0.4324 \times \mathrm{kg}$ of milk $)+(16.216 \times \mathrm{kg}$ of milk fat $)]$. 
Table 5. Body weight, BCS, and calculated energy values for cows fed experimental diets in late lactation

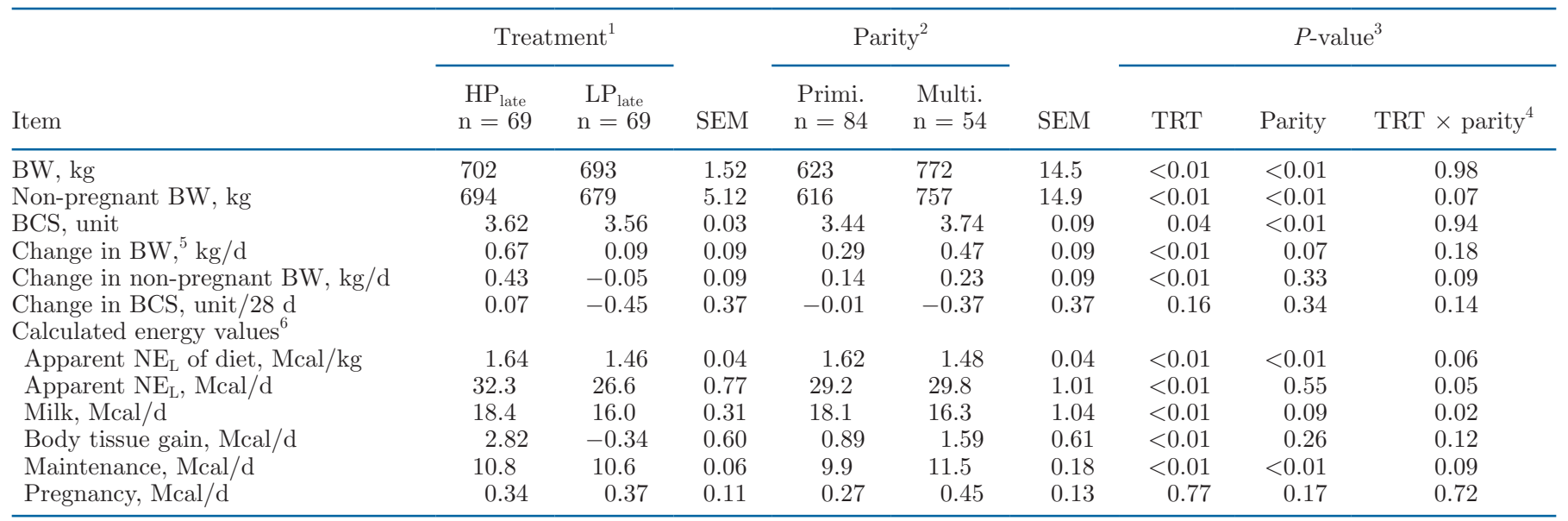

${ }^{1}$ Treatments contained $16 \% \mathrm{CP}\left(\mathrm{HP}_{\text {late }}\right)$ and $13 \% \mathrm{CP}\left(\mathrm{LP}_{\text {late }}\right)$ on a DM basis for late-lactation cows.

${ }^{2}$ Primi. = primiparous cows; multi. = multiparous cows.

${ }^{3} P$-value associated with treatment differences $\left(\mathrm{HP}_{\text {late }} \mathrm{vs} . \mathrm{LP}_{\text {late }} ; \mathrm{TRT}\right)$ and parity differences (primi vs. multi.; parity) in late-lactation cows.

${ }^{4}$ Values within each TRT $\times$ parity interaction are shown in Supplemental Table S1 (https://doi.org/10.3168/jds.2019-17567)

${ }^{5}$ Determined by linear regression using BW measurements throughout the period.

${ }^{6}$ Milk $($ MilkE $)=[9.29 \times$ fat $(\mathrm{kg})+5.63 \times$ true protein $(\mathrm{kg})+3.95 \times$ lactose $(\mathrm{kg})]$. Body tissue gain $(\Delta$ BodyE $)=[(2.88+1.036 \times \mathrm{BCS}) \times$ $\Delta \mathrm{BW}]$, where $\Delta \mathrm{BW}=$ change in $\mathrm{BW}$. Maintenance $=0.08 \times \mathrm{MBW}$, where $\mathrm{MBW}=$ metabolic $\mathrm{BW}\left(\mathrm{BW}^{0.75}\right)$.

moderately repeatable across $\mathrm{HP}$ and $\mathrm{LP}$ diets $(\mathrm{r}=$ $0.59, P<0.01)$. Figure 1 illustrates the relationship between RFI in $\mathrm{HP}_{\text {peak }}$ and RFI in $\mathrm{LP}_{\text {peak. }}$. In late lactation, RFI was less repeatable across protein levels than it was in peak lactation $(\mathrm{r}=0.41, P=0.03)$. Figure 2 illustrates the relationship between RFI in $\mathrm{HP}_{\text {late }}$ and RFI in $\mathrm{LP}_{\text {late }}$. A moderate level of correlation between $\mathrm{RFI}_{\text {high }}$ and $\mathrm{RFI}_{\text {low }}$ was observed $(\mathrm{r}=0.51, P<0.01)$. The Pearson correlation coefficient across peak and late lactation was $0.52(P<0.01)$ for DMI, $0.05(P=0.67)$ for MilkE, $0.05(P=0.67)$ for $\triangle$ BodyE, and $0.91(P<$ $0.01)$ for MBW.

Based on the data from 69 cows examined in both peak and late lactations, the repeatability of RFI was low across lactation stage for the HP diets $(\mathrm{r}=0.11$, $P=0.39)$ but moderate across lactation stage for the LP diets $(\mathrm{r}=0.28, P=0.02)$. The correlation between $\mathrm{RFI}_{\text {peak }}$ and $\mathrm{RFI}_{\text {late }}$ for both diets combined was moderate $(\mathrm{r}=0.25, P=0.04)$. Further details are shown in Table 7 and Figure 3.

Table 6. Partial regression coefficients of the RFI models in peak- and late-lactation cows

\begin{tabular}{|c|c|c|c|c|c|c|c|c|c|c|}
\hline \multirow{2}{*}{ Item } & \multicolumn{5}{|c|}{ Peak lactation } & \multicolumn{5}{|c|}{ Late lactation } \\
\hline & Coefficient & SEM & $P$-value & \multicolumn{2}{|c|}{ Contribution to DMI } & Coefficient & SEM & $P$-value & \multicolumn{2}{|c|}{ Contribution to DMI } \\
\hline Intercept & -3.22 & 2.48 & 0.18 & & & 2.26 & 2.46 & 0.36 & & \\
\hline MilkE $^{1}$ & 0.44 & 0.03 & $<0.01$ & 10.8 & 2.18 & 0.37 & 0.03 & $<0.01$ & 6.51 & 1.73 \\
\hline $\mathrm{MBW}^{2}$ & 0.06 & 0.01 & $<0.01$ & 8.99 & 0.85 & 0.08 & 0.02 & $<0.01$ & 10.7 & 1.15 \\
\hline $\mathrm{BCS}$ & 0.45 & 0.31 & 0.16 & & & -0.19 & 0.44 & 0.68 & & \\
\hline Parity & -1.06 & 0.28 & $<0.01$ & & & -1.08 & 0.41 & $<0.01$ & & \\
\hline DIM & 0.07 & 0.03 & 0.02 & & & 0.03 & 0.007 & $<0.01$ & & \\
\hline $\mathrm{DIM} \times \mathrm{DIM}$ & -0.0002 & 0.0001 & 0.04 & & & & & & & \\
\hline Experiment & 0.13 to 3.03 & & & & & -1.09 to -0.49 & & & & \\
\hline Cohort & -1.49 to 1.65 & & & & & -0.92 to -0.22 & & & & \\
\hline
\end{tabular}

${ }^{1}$ MilkE $=$ milk energy $(\mathrm{Mcal} / \mathrm{d})=[9.29 \times$ fat $(\mathrm{kg})+5.63 \times$ true protein $(\mathrm{kg})+3.95 \times$ lactose $(\mathrm{kg})]$.

${ }^{2} \mathrm{MBW}=$ metabolic $\mathrm{BW}(\mathrm{kg})=\mathrm{BW}^{0.75}$.

${ }^{3}$ Energy utilized in body tissue gain $(\mathrm{Mcal} / \mathrm{d})=[(2.88+1.036 \times \mathrm{BCS}) \times \Delta \mathrm{BW}]$.

${ }^{4}$ Pregnancy energy $(\mathrm{Mcal} / \mathrm{d})=[(0.00318 \times \mathrm{D}-0.0352) \times(\mathrm{CBW} / 45)] / 0.218$, where $\mathrm{D}$ was day of gestation between 190 and 279 , and CBW was the calf birth weight. 


\section{RFI and Protein Efficiency}

Overall, cows with lower RFI values exhibited higher protein efficiency. For cows in peak lactation, the Pearson correlation coefficient between RFI and milk protein efficiency was $-0.59(P<0.01)$ in $\mathrm{HP}_{\text {peak }}$ diets and $-0.41(P<0.01)$ in $\mathrm{LP}_{\text {peak }}$ diets. For cows in late lactation, the Pearson correlation coefficient between RFI and milk protein efficiency was $-0.36(P=0.02)$ in $\mathrm{HP}_{\text {late }}$ diets and $-0.13(P=0.34)$ in $\mathrm{LP}_{\text {late }}$ diets. The correlation coefficient between RFI and milk protein efficiency across diets was $-0.42(P<0.01$; Figure 4$)$ among peak-lactation cows and $-0.24(P=0.06$; Figure 5) among late-lactation cows. Similar associations between RFI and gross protein efficiency were also observed in the current study, as MPE and GPE were highly correlated in both peak lactation $(\mathrm{r}=0.83, P<$ $0.01)$ and late lactation $(\mathrm{r}=0.89, P<0.01)$.

As shown in Table 8, cows with lower RFI values during peak lactation had higher milk protein efficiency and gross protein efficiency regardless of protein con- tent in the diet; however, cows with lower RFI values did not necessarily have lower MUN concentration. Similar trends were observed in cows fed HP diets in late lactation. In contrast, when fed LP diets, cows with lower RFI in late lactation did not exhibit greater protein efficiency (MPE, GPE) nor MUN.

\section{DISCUSSION}

\section{Animal Performance Across Dietary Protein Levels and Lactation Stages}

Overall, cows had lower feed intake and milk production when fed LP diets, regardless of lactation stage. Production differences between HP and LP cows were most likely the result of additional RUP supplementation in HP diets and, thus, inadequate metabolizable protein in the LP diets. The LP diets also decreased gains in BW and BCS. Significantly lower gains in BW than in body condition might be due to the slightly lower intakes of LP cows or might indicate that cows

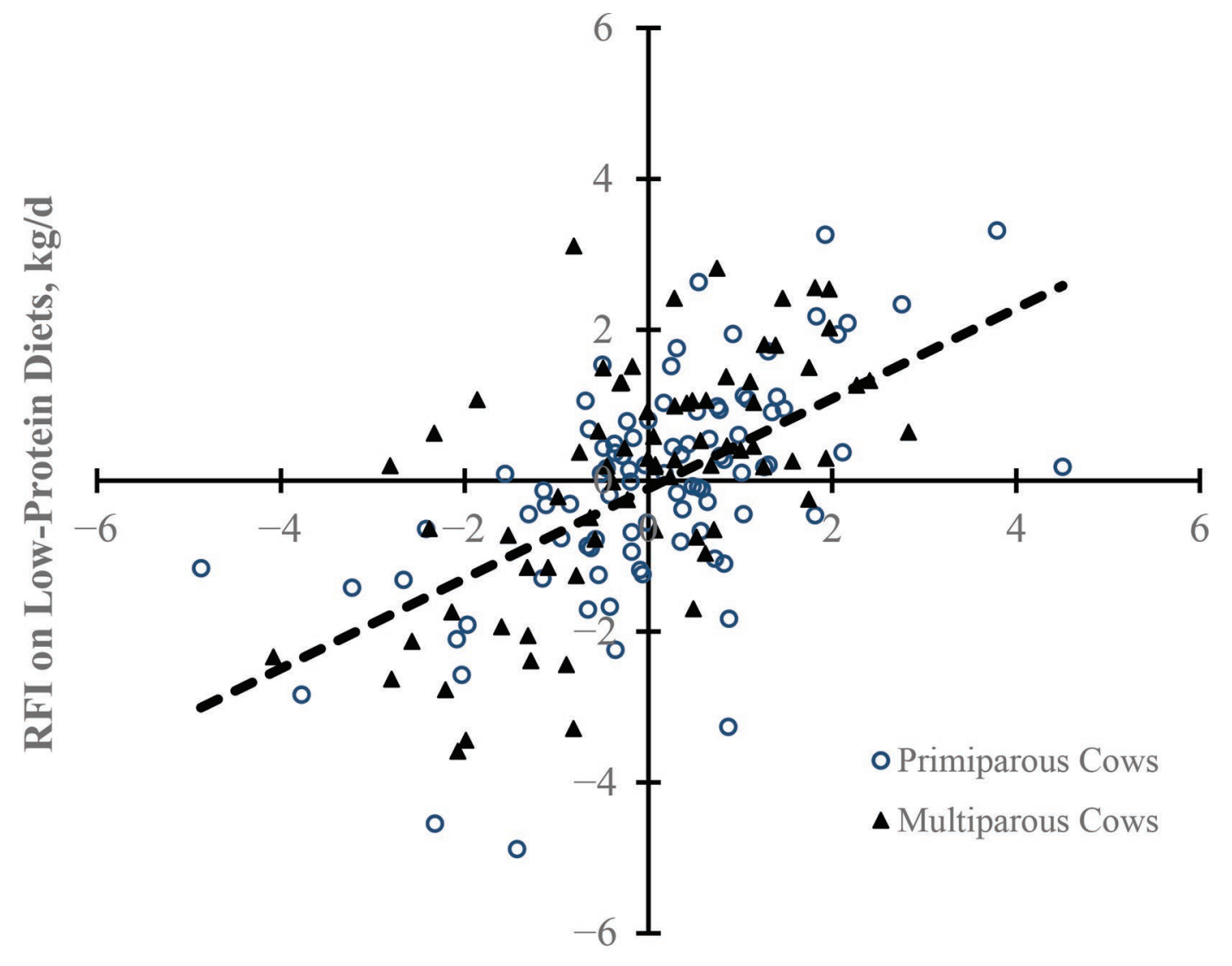

RFI on High-Protein Diets, kg/d

Figure 1. Repeatability of residual feed intake (RFI) across dietary protein levels in peak-lactation cows $(\mathrm{n}=166)$. Repeatability of RFI across dietary protein levels was $\mathrm{r}=0.59$. RFI on low-protein diets could be predicted using RFI on high-protein diets as $\mathrm{Y}=0.628( \pm 0.062 ; P$ $<0.01) \times X-0.000( \pm 0.09)$. Each data point represents 1 cow's RFI value on each diet $(\mathrm{n}=166)$. Open circles indicate primiparous cows $(\mathrm{n}$ $=92)$, and filled triangles indicate multiparous cows $(\mathrm{n}=74)$. 
Table 7. Repeatability of residual feed intake (RFI) across protein levels within lactation stage and across lactation stages $(\mathrm{n}=69)$

\begin{tabular}{|c|c|c|c|c|c|c|c|}
\hline Item $^{1}$ & $\mathrm{RFI}_{\text {LPpeak }}$ & $\mathrm{RFI}_{\text {peak }}^{2}$ & $\mathrm{RFI}_{\text {high }}{ }^{3}$ & $\mathrm{RFI}_{\text {HPlate }}$ & $\mathrm{RFI}_{\text {LPlate }}$ & $\mathrm{RFI}_{\text {late }}{ }^{4}$ & $\mathrm{RFI}_{\text {low }}$ \\
\hline \multirow[t]{2}{*}{$\mathrm{RFI}_{\text {HP peak }}$} & 0.59 & 0.84 & 0.77 & 0.11 & 0.11 & 0.13 & 0.40 \\
\hline & $<0.01$ & $<0.01$ & $<0.01$ & 0.39 & 0.39 & 0.31 & $<0.01$ \\
\hline \multirow[t]{2}{*}{$\mathrm{RFI}_{\text {LPpeak }}$} & & 0.87 & 0.46 & 0.20 & 0.28 & 0.28 & 0.86 \\
\hline & & $<0.01$ & $<0.01$ & 0.10 & 0.02 & 0.02 & $<0.01$ \\
\hline \multirow[t]{2}{*}{$\mathrm{RFI}_{\text {peak }}^{2}$} & & & 0.84 & 0.23 & 0.23 & 0.25 & 0.73 \\
\hline & & & $<0.01$ & 0.06 & 0.05 & 0.04 & $<0.01$ \\
\hline \multirow[t]{2}{*}{$\mathrm{RFI}_{\text {high }}{ }^{3}$} & & & & 0.76 & 0.34 & 0.70 & 0.51 \\
\hline & & & & $<0.01$ & $<0.01$ & $<0.01$ & $<0.01$ \\
\hline \multirow[t]{2}{*}{$\mathrm{RFI}_{\text {HPlate }}$} & & & & & 0.41 & 0.85 & 0.36 \\
\hline & & & & & $<0.01$ & $<0.01$ & $<0.01$ \\
\hline \multirow{2}{*}{$\mathrm{RFI}_{\text {LPlate }}$} & & & & & & 0.82 & 0.73 \\
\hline & & & & & & $<0.01$ & $<0.01$ \\
\hline \multirow[t]{2}{*}{$\mathrm{RFI}_{\text {late }}{ }^{4}$} & & & & & & & 0.64 \\
\hline & & & & & & & $<0.01$ \\
\hline
\end{tabular}

${ }^{1}$ Upper values within a row $=$ Pearson correlation coefficient of the linear relationship between 2 variables. Lower values within a row $=P$-value associated with the linear relationship between 2 variables.

${ }^{2}$ Averaged RFI across the diets fed to cows in peak lactation.

${ }^{3}$ Averaged RFI in high-protein (HP) diets across lactation stages.

${ }^{4}$ Averaged RFI across the diets fed to cows in late lactation.

${ }^{5}$ Averaged RFI in low-protein (LP) diets across lactation stage.

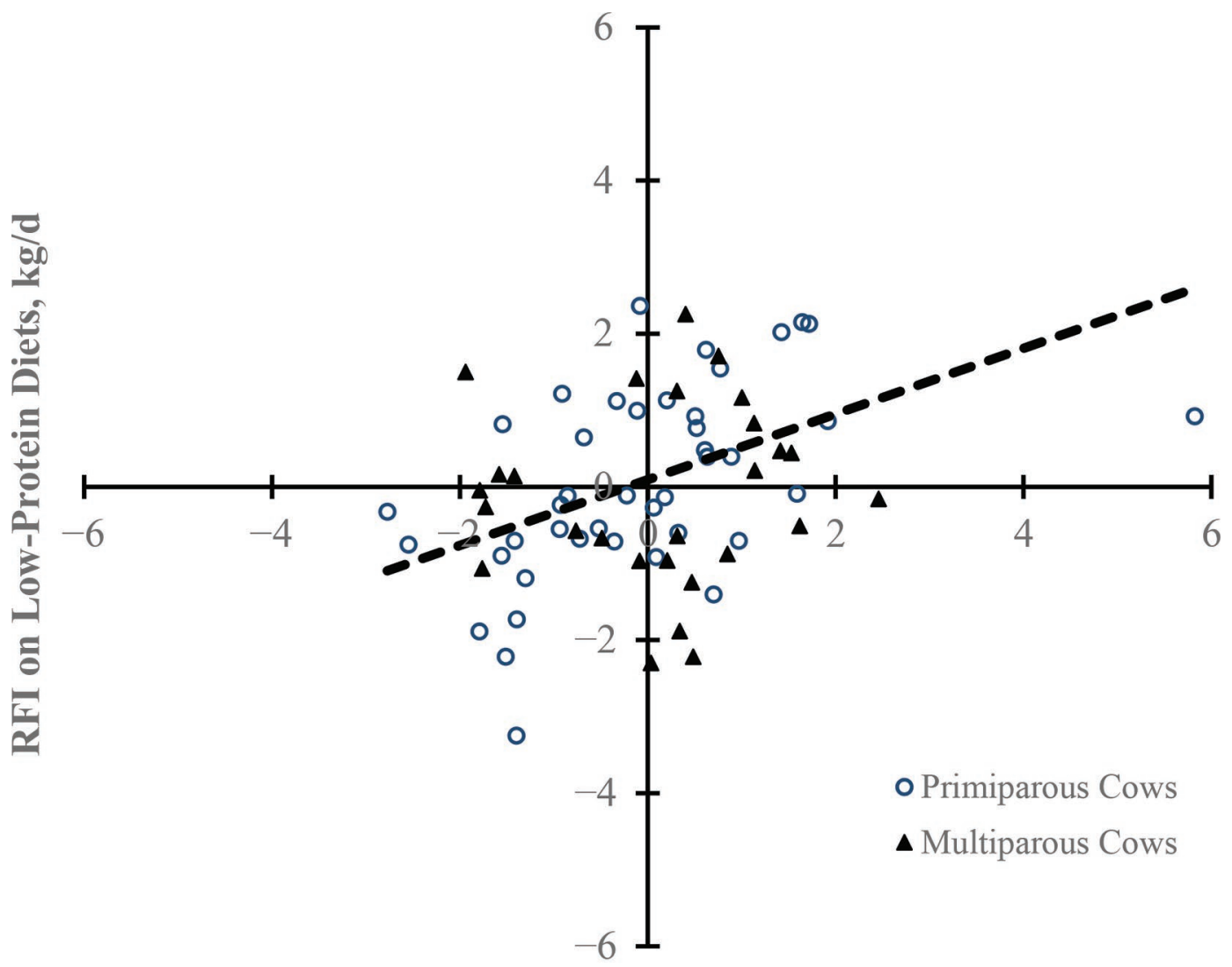

\section{RFI on High-Protein Diets, kg/d}

Figure 2. Repeatability of residual feed intake (RFI) across dietary protein levels in late-lactation cows $(\mathrm{n}=69)$. Repeatability of RFI across dietary protein levels was $\mathrm{r}=0.41$. RFI on low-protein diets could be predicted using RFI on high-protein diets as $\mathrm{Y}=0.387( \pm 0.101 ; P<$ $0.01) \times X-0.000( \pm 0.14)$. Each data point represents 1 cow's RFI value on each diet $(\mathrm{n}=69)$. Open circles indicate primiparous cows $(\mathrm{n}=$ $42)$, and filled triangles indicate multiparous cows $(\mathrm{n}=27)$. 
tended to gain less body protein than fat when fed LP diets.

With a similar decrease in dietary protein content, the decrease of feed intake and milk production was similar between peak- and late-lactation cows; however, late-lactation cows tended to lose more non-pregnant BW and BCS than peak-lactation cows (Tables 3 and $5)$. We suggest that nutrients were prioritized to pregnancy and milk synthesis instead of body tissue gain when protein was limiting in late lactation. Indeed, Bauman and Currie (1980) found that the priority of nutrient partitioning in cattle was pregnancy, followed by milk production, and lastly body reserve gain; our data were consistent with this idea.

\section{Repeatability of RFI Across Protein Levels and Lactation Stages}

Although production was significantly altered by the diets, RFI within cows was still repeatable across dietary protein levels within each lactation stage. The existing literature on RFI repeatability has predominantly focused on peak-lactation cows. The current study supports previous studies on RFI repeatability and extends RFI repeatability across diets to latelactation cows. Among peak-lactation cows, the moderate level of RFI repeatability found in the current study (0.59) was in line with the findings of previous RFI repeatability studies, where RFI was repeatable across starch contents (0.73; Potts et al., 2015) and forage NDF contents (0.54; Carrasquillo-Mangual et al., 2016). According to Richardson and Herd (2004), the major contributor to the variation of RFI in cattle is "tissue metabolism and protein turnover." We expect that treatments altering these processes might significantly alter RFI and therefore alter RFI repeatability. Wessels et al. (1997) showed that supplementing amino acids alters protein turnover. Thus, the lower level of RFI repeatability in the current study, compared with the findings of Potts et al. (2015), might be related to the expected changes in protein metabolism when altering dietary protein. Lower RFI repeatability across

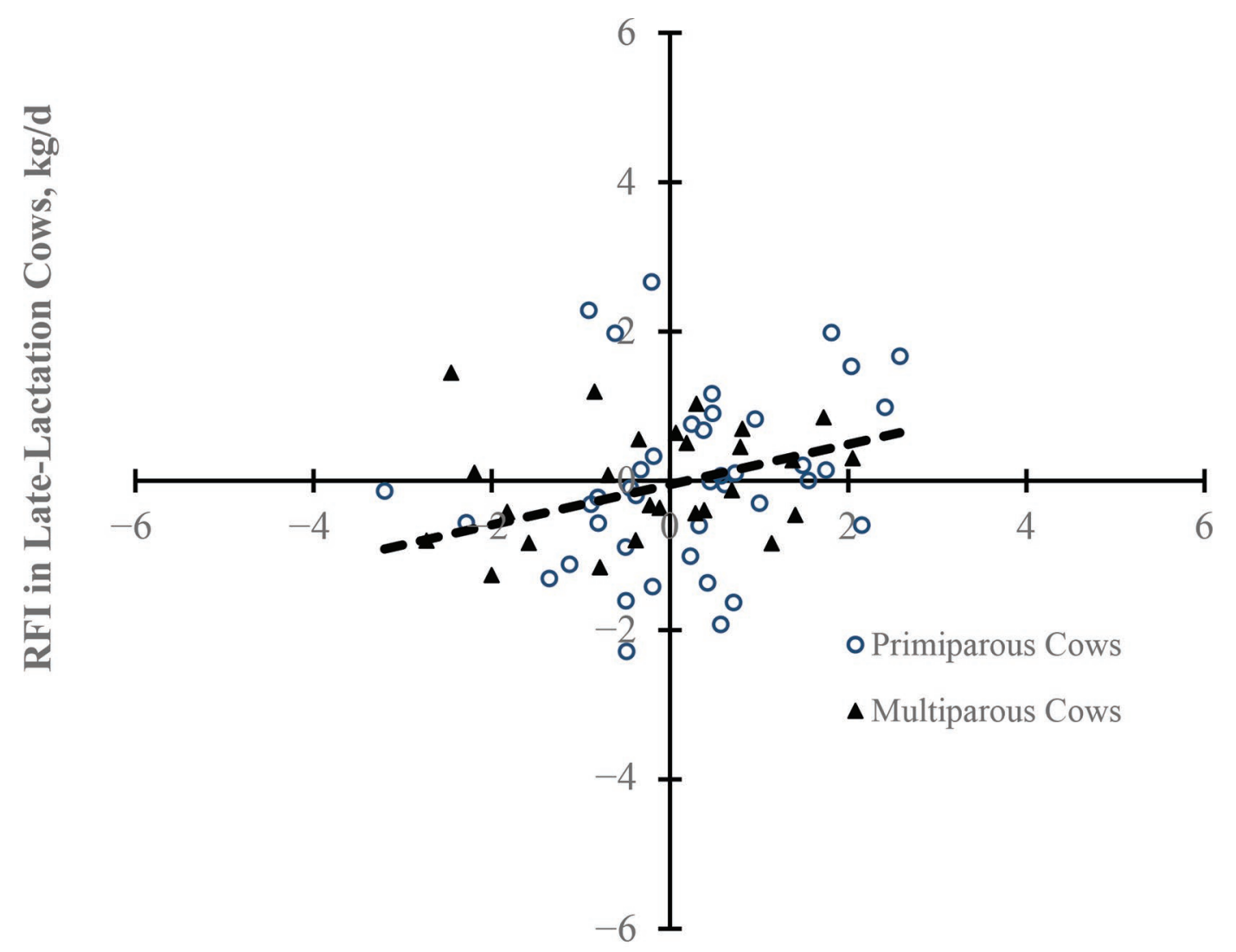

RFI in Peak-Lactation Cows, $\mathrm{kg} / \mathrm{d}$

Figure 3. Repeatability of residual feed intake (RFI) across lactation stages in lactating cows ( $\mathrm{n}=69)$. Repeatability of RFI across lactation stages was $\mathrm{r}=0.25$. RFI in late-lactation cows could be predicted using RFI in peak-lactation cows as $\mathrm{Y}=0.198( \pm 0.097 ; P=0.02) \times$ $\mathrm{X}-0.009( \pm 0.12)$. Each data point represents 1 cow's RFI value in each stage $(\mathrm{n}=69)$. Open circles indicate primiparous cows $(\mathrm{n}=42)$, and filled triangles indicate multiparous cows $(\mathrm{n}=27)$. 
dietary protein levels in late lactation, compared with peak lactation, was expected due to the uncertainty of pregnancy weight gain, which will be further discussed.

Repeatability of RFI across physiological state, as across lactation stage in the current study, has been reported previously. Phenotypic correlation of RFI was low, either when compared across weaned beef heifers later tested as lactating cows (Archer et al., 2002) or when estimated in growing dairy heifers that were later tested during lactation (Nieuwhof et al., 1992; Williams et al., 2011; Waghorn et al., 2012). The work done by Liinamo et al. (2015) and Li et al. (2017) demonstrated that genetic RFI values estimated from various lactation stages were different, and the difference was extremely evident when comparing the RFI estimated from early lactation with that estimated from late lactation. Although the DMI was moderately repeatable $(\mathrm{r}=0.52)$ across lactation stages in the current study, given the low repeatability of the major energy sinks, especially MilkE, the low RFI repeatability was fully expected. The low RFI repeatability across lactation stage could be due to the following reasons: (1) mechanisms controlling energy efficiency (or partitioning) shifted as lactation proceeded, and (2) our estimates of body energy change were not accurate and were altered by lactation stage. Throughout lactation, dairy cows undergo physiological changes, including (1) body reserve mobilization in early lactation, (2) body tissue replenishment in mid-lactation, and (3) storage of extra body fat in late lactation. We used BW change and $\mathrm{BCS}$ to predict energy change; however, BW change also included change in gut content and pregnancy gain, and body composition could not be fully represented by BCS. Practically, RFI is an adjusted DMI after accounting for energy partitioning to milk, body tissue gain, maintenance, and pregnancy (in late lactation); thus, any errors in estimating these energy sinks can introduce errors in calculating RFI.

Errors in BW change could introduce significant bias in the RFI estimation (Potts et al., 2015). This

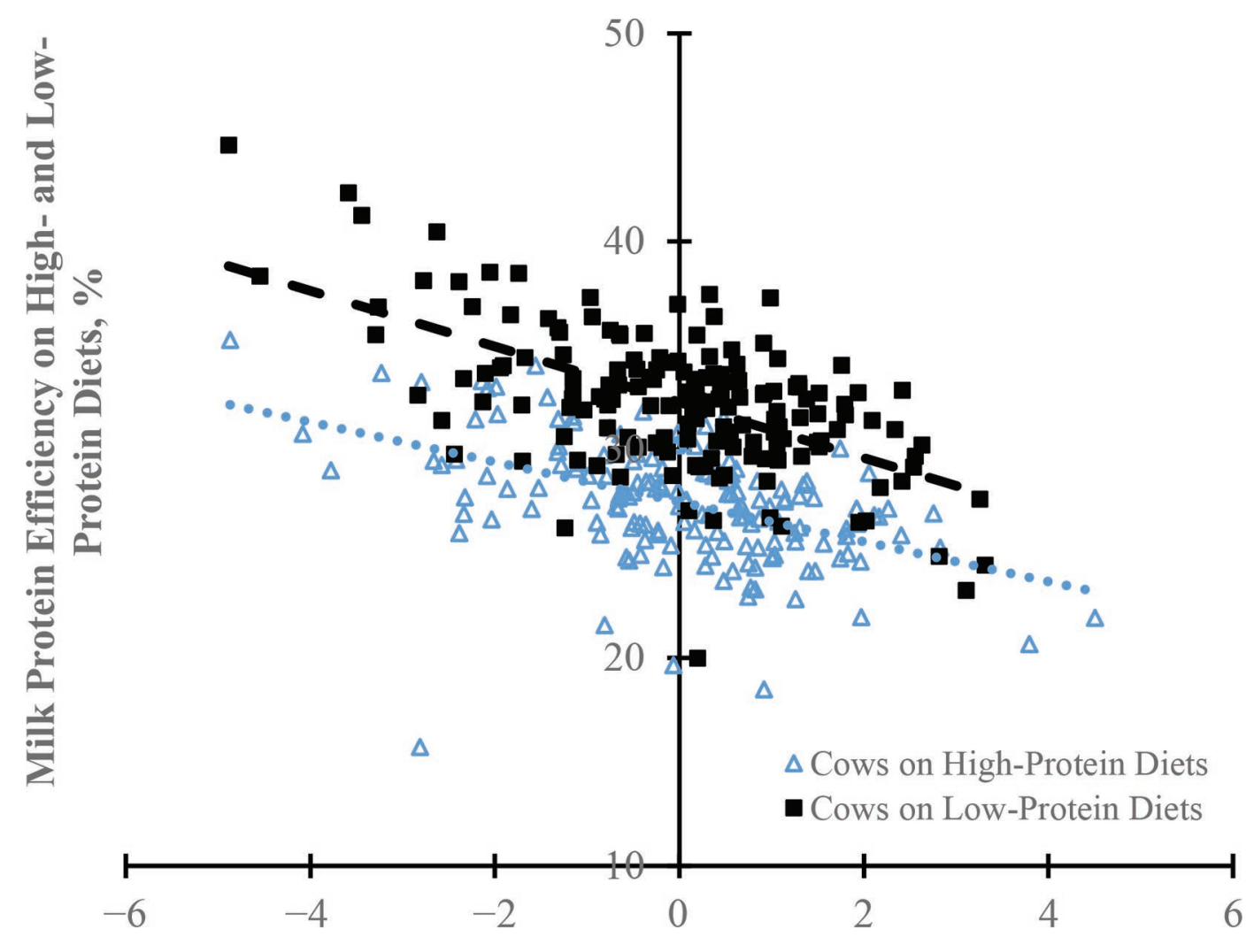

RFI on High- and Low-Protein Diets, kg/d

Figure 4. Association between residual feed intake (RFI) and milk protein efficiency (MPE) in peak-lactation cows ( $\mathrm{n}=332$ ). In peaklactation cows, correlation between RFI and MPE across high- and low-protein diets was -0.42 . The correlation between RFI and MPE in high-protein diets was $-0.59[\mathrm{MPE}=-0.96( \pm 0.14 ; P<0.01) \times \mathrm{RFI}+27.5( \pm 0.20 ; P<0.01)]$, and the correlation between RFI and MPE in low-protein diets was $-0.41[\mathrm{MPE}=-1.34( \pm 0.14 ; P<0.01) \times \mathrm{RFI}+32.3( \pm 0.21 ; P<0.01)]$. Each data point represents 1 cow's RFI value on each diet. Open triangles indicate cows on high-protein diets $(\mathrm{n}=166)$, and filled squares indicate cows on low-protein diets $(\mathrm{n}=166)$. 
Table 8. Protein efficiency and MUN of high-, medium-, and low-residual feed intake (RFI) cows fed high- and low-protein diets in peak and late lactation

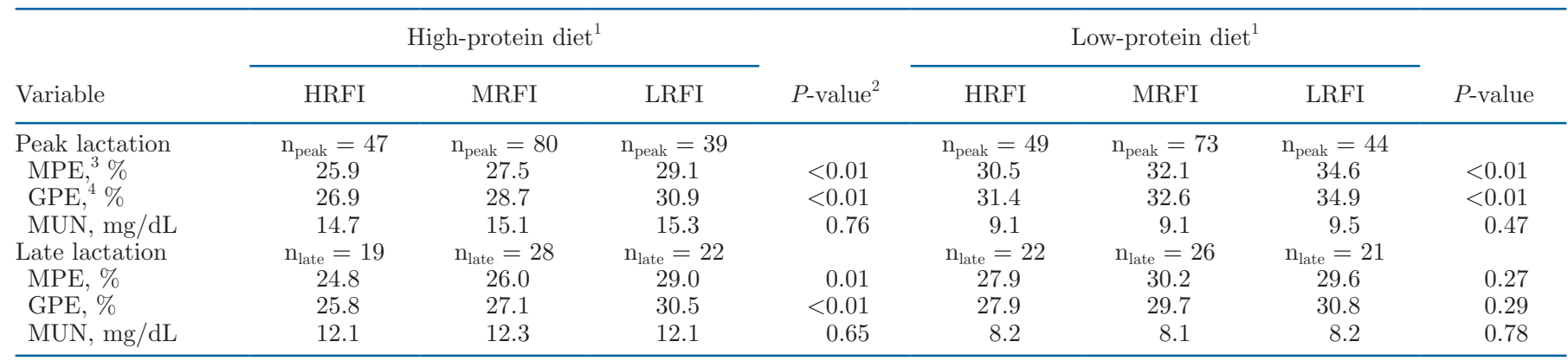

${ }^{1}$ Cows were grouped into high- (HRFI), medium- (MRFI), and low-RFI (LRFI) groups. Cows $>0.5$ SD of the mean RFI for a cohort were classified as HRFI, cows $<-0.5 \mathrm{SD}$ were classified as LRFI, and those $\pm 0.5 \mathrm{SD}$ were classified as MRFI.

${ }^{2} P$-value associated with group difference.

${ }^{3} \mathrm{MPE}=$ milk protein efficiency, defined as the dietary protein captured in milk.

${ }^{4} \mathrm{GPE}=$ gross protein efficiency, defined as dietary protein captured in milk and body tissue.

becomes especially important when estimating RFI for late-lactation cows. Change in BW among latelactation cows was calculated from adjusted BW after deducting conceptus weight from measured BW. Given the difficulty in getting a precise estimate of conceptus weight, BW change in late-lactation cows could not

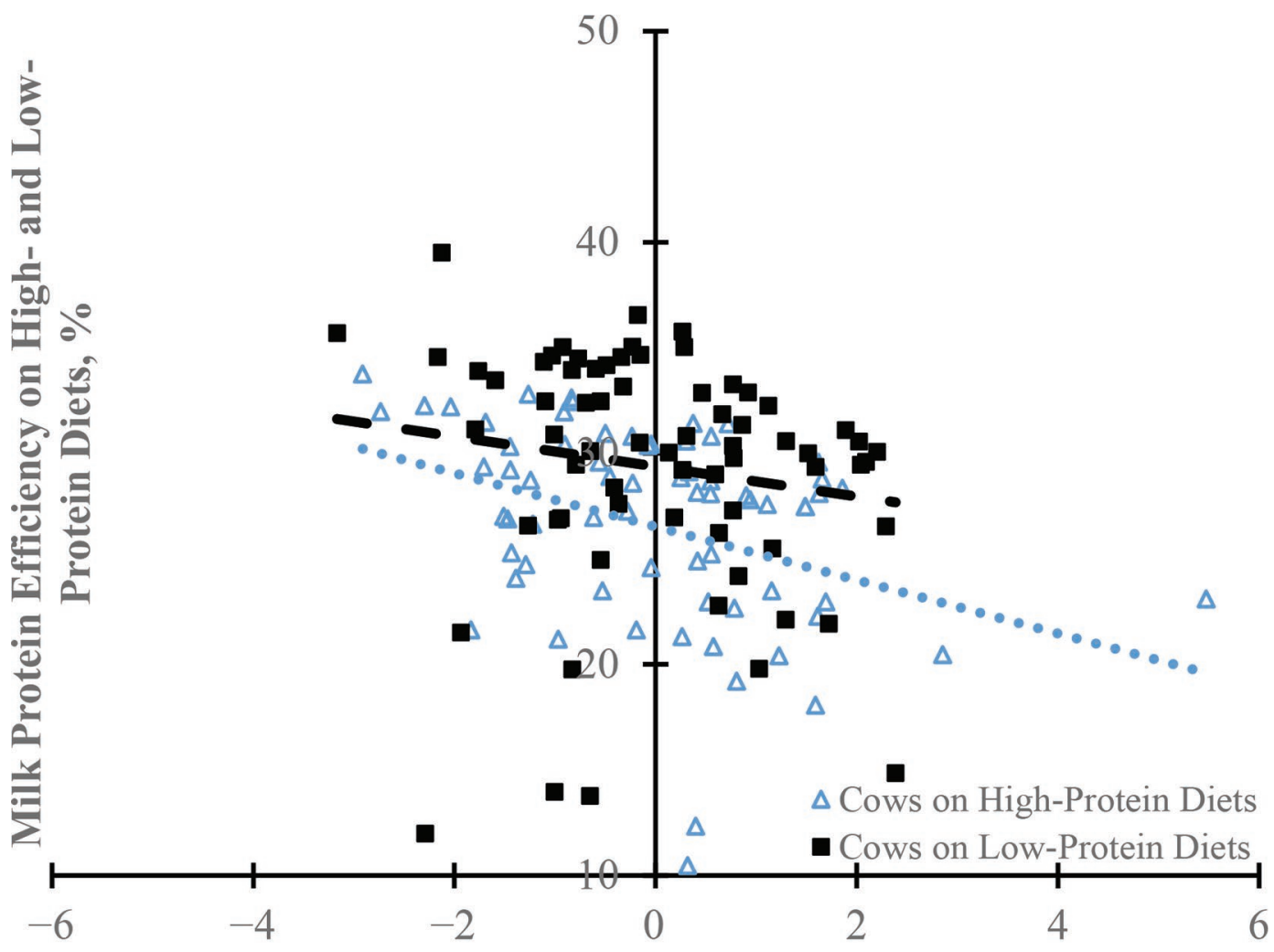

RFI on High- and Low-Protein Diets, kg/d

Figure 5. Association between residual feed intake (RFI) and milk protein efficiency (MPE) in late-lactation cows ( $\mathrm{n}=138)$. In late-lactation cows, correlation between RFI and MPE across high- and low-protein diets was -0.24 . The correlation between RFI and MPE in high-protein diets was $-0.36[\mathrm{MPE}=-1.27( \pm 0.42 ; P<0.01) \times \mathrm{RFI}+26.5( \pm 0.58 ; P<0.01)]$, and the correlation between RFI and MPE in low-protein diets was $-0.13[\mathrm{MPE}=-0.71( \pm 0.55 ; P=0.20) \times \mathrm{RFI}+29.4( \pm 0.68 ; P<0.01)]$. Each data point represents 1 cow's RFI value on each diet. Open triangles indicate cows on high-protein diets $(\mathrm{n}=138)$, and filled squares indicate cows on low-protein diets $(\mathrm{n}=138)$. 
be quantified as accurately as it was in peak-lactation cows. Therefore, more errors could be introduced in estimating RFI among late-lactation cows. Additionally, the difficulty in assessing conceptus weight can also contribute to errors in estimating energy utilized in pregnancy. As errors were introduced in the 2 primary energy sinks, we expected that the estimated value of RFI would be less accurate among late-lactation cows. Indeed, due to the difficulty of estimating BW change, Prendiville et al. (2011) advised estimating RFI based on data between DIM 150 and DIM 230, when tissue gain or loss was minimal, to generate the most accurate estimates of RFI.

\section{RFI and Protein Efficiency}

No prior study has directly examined the relationship between RFI and protein efficiency among lactating Holstein cows; however, the relationship between RFI and protein efficiency in growing heifers has been examined. Rius et al. (2012) observed no difference in nitrogen efficiency between 2 groups of Holstein-Friesian heifers with divergent RFI values. Following that, the work done by Thornhill et al. (2014) and Marett et al. (2017) further showed that cows selected for lower RFI as calves or heifers did not have higher nitrogen efficiency in the subsequent lactation. In contrast with the heifer studies, the results of the current study suggested that RFI is strongly associated with protein efficiency in peak-lactation cows and also in late-lactation cows when protein is not limiting.

$\mathrm{Xi}$ et al. (2016) and Carrasquillo-Mangual et al. (2016) speculated that lactating cows with lower RFI values might have higher protein efficiency, as indicated by the lower MUN values in their low-RFI cows. Prior work showed that protein turnover rates could be negatively associated with protein utilization efficiency in dairy cows (Herd et al., 2004; Castro Bulle et al., 2007). Previous study also suggested that higher protein turnover rates were related to higher RFI values in cattle (Richardson et al., 2004). Based on these prior works, we expected a negative association between RFI and protein efficiency. Indeed, the current study directly proves that this negative relationship exists in most cases, unless protein is limiting for pregnant cows. This poor correlation could be due to the nutrient repartitioning to pregnancy when protein was limiting in pregnant cows. Therefore, when pregnancy does not take priority over milk synthesis, cows with lower RFI should utilize protein more efficiently.

The moderate correlation between RFI and protein efficiency provides a new means to genetically improve protein efficiency in dairy cattle. Although a moderate level of heritability for protein efficiency has been shown to exist in lactating dairy cows (0.10 to 0.31 ; Li et al.,1998; Zamani et al., 2011), directly selecting dairy cows based on ratio traits (e.g., protein efficiency) has drawbacks. Ratio traits are usually not normally distributed. As a result, it is difficult to expect the selection response due to the disproportionate selection pressure on the component traits (Zetouni et al., 2017). In other words, using ratio traits (e.g., the protein efficiency term) in genetic selection induces large error variance and unexpected results. In contrast, RFI, as a residual term, overcomes all the drawbacks of ratio traits and is favorable in cow selection. However, due to the complexity of collecting individual intake data, estimating RFI is still difficult in dairy cows.

\section{CONCLUSIONS}

Low-protein diets significantly decreased feed intake, milk production, BW, energy captured in milk and body tissue, and feed efficiency in both peak- and latelactation cows. Within each lactation stage, RFI was moderately repeatable across dietary protein levels; similarly, average RFI in HP and LP diets across lactation stage was also moderately repeatable. Thus, we expect that cows with lower RFI when fed diets with adequate protein, as is typical for North America, will still have lower RFI when fed diets marginally deficient in protein. Lastly, cows with lower RFI values utilized protein more efficiently. We suggest that protein efficiency will be improved in the process of selecting dairy cattle based on RFI.

\section{ACKNOWLEDGMENTS}

We thank J. S. Liesman and the staff of the Michigan State University Dairy Cattle Teaching and Research Center (East Lansing, MI) for their assistance in these experiments, and Landus Cooperative (Ames, IA) for donating SoyPlus soybean meal. This project was supported by Agriculture and Food Research Initiative Competitive Grant no. 2011-68004-30340 from the USDA National Institute of Food and Agriculture (Washington, DC) and funds from the Michigan Alliance for Animal Agriculture (East Lansing) and Michigan AgBioResearch (East Lansing). The authors have not stated any conflicts of interest.

\section{REFERENCES}

AOAC. 1990. Official Methods of Analysis. 15th ed. Association of Official Analytical Chemists, Gaithersburg, MD.

Archer, J. A., A. Reverter, R. M. Herd, D. J. Johnston, and P. F. Arthur. 2002. Genetic variation in feed intake and efficiency of mature beef cows and relationships with post weaning measurements. 7th World Congr. Genet. Appl. Livest. Prod. 31:221-224. 
Bauman, D. E., and W. B. Currie. 1980. Partitioning of nutrients during pregnancy and lactation: A review of mechanisms involving homeostasis and homeorhesis. J. Dairy Sci. 63:1514-1529.

Broderick, G. A., A. P. Faciola, and L. E. Armentano. 2015. Replacing dietary soybean meal with canola meal improves production and efficiency of lactating dairy cows. J. Dairy Sci. 98:5672-5687.

Carrasquillo-Mangual, M.J., E. Liu, and M. J. VandeHaar. 2016. Repeatability of residual feed intake across dietary forage concentration. J. Animal Sci. 94(Suppl. 5):348-349.

Castro Bulle, F. C. P., P. V. Paulino, A. C. Sanches, and R. D. Sainz. 2007. Growth, carcass quality, and protein and energy metabolism in beef cattle with different growth potentials and residual feed intakes. J. Anim. Sci. 85:928-936.

Connor, E. E. 2015. Invited review: Improving feed efficiency in dairy production: Challenges and possibilities. Animal 9:395-408.

Gidlund, H., M. Hetta, S. J. Krizsan, S. Lemosquet, and P. Huhtanen. 2015. Effects of soybean meal or canola meal on milk production and methane emissions in lactating dairy cows fed grass silagebased diets. J. Dairy Sci. 98:8093-8106.

Herd, R. M., V. H. Oddy, and E. C. Richardson. 2004. Biological basis for variation in residual feed intake in beef cattle. 1. Review of potential mechanisms. Aust. J. Exp. Agric. 44:423-430.

Huhtanen, P., and A. N. Hristov. 2009. A meta-analysis of the effects of dietary protein concentration and degradability on milk protein yield and milk N efficiency in dairy cows. J. Dairy Sci. 92:3222-3232.

Koch, R. M., L. A. Swiger, D. Chambers, and K. E. Gregory. 1963. Efficiency of feed use in beef cattle. J. Anim. Sci. 22:486-494.

Li, B., B. Berglund, W. F. Fikse, J. Lassen, M. H. Lidauer, P. Mäntysaari, and P. Løvendahl. 2017. Neglect of lactation stage leads to naive assessment of residual feed intake in dairy cattle. J. Dairy Sci. 100:9076-9084.

Li, J., D. Chen, and S. Xu. 1998. The analysis on genetic factors of feed energy and protein efficiency of Chinese Simmental. Pages 133-136 in Proc. 6th World Congress on Genetics Applied in Livestock Production, Armidale, NSW, Australia. University of New England.

Liinamo, A.-E., P. Mantysaari, M. H. Lidauer, and E. A. Mantysaari. 2015. Genetic parameters for residual energy intake and energy conversion efficiency in Nordic Red dairy cattle. Acta Agric. Scand. A Anim. Sci. 65:63-72.

Marett, L. C., S. R. O. Williams, B. J. Hayes, J. E. Pryce, and W. J. Wales. 2017. Partitioning of energy and nitrogen in lactating primiparous and multiparous Holstein-Friesian cows with divergent residual feed intake. Anim. Prod. Sci. 57:1499-1506.

Nieuwhof, G. J., J. A. M. Van Arendonk, H. Vos, and S. Korver. 1992. Genetic relationships between feed intake, efficiency and production traits in growing bulls, growing heifers and lactating heifers. Livest. Prod. Sci. 32:189-202.

NRC. 2001. Nutrient Requirements of Dairy Cattle. 7th rev. ed. Natl. Acad. Press, Washington, DC.

Potts, S. B., J. P. Boerman, A. L. Lock, M. S. Allen, and M. J. VandeHaar. 2015. Residual feed intake is repeatable for lactating Holstein dairy cows fed high and low starch diets. J. Dairy Sci. 98:4735-4747.

Prendiville, R., K. M. Pierce, L. Delaby, and F. Buckley. 2011. Animal performance and production efficiencies of Holstein-Friesian, Jersey and Jersey $\times$ Holstein-Friesian cows throughout lactation. Livest. Sci. 138:25-33.

Pryce, J. E., J. Arias, P. J. Bowman, S. R. Davis, K. A. Macdonald, G. C. Waghorn, and B. J. Hayes. 2012. Accuracy of genomic predictions of residual feed intake and 250-day body weight in growing heifers using 625,000 single nucleotide polymorphism markers. J. Dairy Sci. 95:2108-2119.

Richardson, E. C., and R. M. Herd. 2004. Biological basis for variation in residual feed intake in beef cattle. 2. Synthesis of results following divergent selection. Aust. J. Exp. Agric. 44:431-440.
Richardson, E. C., R. M. Herd, J. A. Archer, and P. F. Arthur. 2004 Metabolic differences in Angus steers divergently selected for residual feed intake. Aust. J. Exp. Agric. 44:441-452.

Rius, A. G., S. Kittelmann, K. A. Macdonald, G. C. Waghorn, P. H. Janssen, and E. Sikkema. 2012. Nitrogen metabolism and rumen microbial enumeration in lactating cows with divergent residual feed intake fed high-digestibility pasture. J. Dairy Sci. 95:50245034 .

Sinclair, K. D., P. C. Garnsworthy, G. E. Mann, and L. A. Sinclair. 2014. Reducing dietary protein in dairy cow diets: Implications for nitrogen utilization, milk production, welfare and fertility. Animal 8:262-274.

St-Pierre, N. R. 2012. The costs of nutrients, comparison of feedstuffs prices and the current dairy situation. Buckeye News. The Ohio State University Extension. Accessed Jul. 20, 2013. http://dairy .osu.edu/bdnews/Volume\%2014\%20issue\%206/Volume\%2014\%20 Issue \% 206.html \#Costs.

Tyrrell, H. F., and J. T. Reid. 1965. Prediction of the energy value of the milk. J. Dairy Sci. 48:1215-1223.

Tempelman, R. J., D. M. Spurlock, M. Coffey, R. F. Veerkamp, L. E. Armentano, K. A. Weigel, and M. J. VandeHaar. 2015. Heterogeneity in genetic and nongenetic variation and energy sink relationships for residual feed intake across research stations and countries. J. Dairy Sci. 98:2013-2026.

Thornhill, J. B., L. C. Marett, M. J. Auldist, J. S. Greenwood, J. E. Pryce, B. J. Hayes, and W. J. Wales. 2014. Whole-tract dry matter and nitrogen digestibility of lactating dairy cows selected for phenotypic divergence in residual feed intake. Anim. Prod. Sci. 54:1460-1464.

VandeHaar, M. J., L. E. Armentano, K. Weigel, D. M. Spurlock, R. J. Tempelman, and R. Veerkamp. 2016. Harnessing the genetics of the modern dairy cow to continue improvements in feed efficiency. J. Dairy Sci. 99:4941-4954.

Waghorn, G. C., K. A. Macdonald, Y. Williams, S. R. Davis, and R. J. Spelman. 2012. Measuring residual feed intake in dairy heifers fed an alfalfa (Medicago sativa) cube diet. J. Dairy Sci. 95:1462-1471.

Wessels, R. H., E. C. Titgemeyer, and G. St. Jean. 1997. Effect of amino acid supplementation on whole-body protein turnover in Holstein steers. J. Anim. Sci. 75:3066-3073.

Wildman, E. E., G. M. Jones, P. E. Wagner, R. L. Boman, H. F. Troutt, and T. N. Lesch. 1982. A dairy cow body condition scoring system and its relationship to selected production characteristics. J. Dairy Sci. 65:495-501.

Williams, Y. J., J. E. Pryce, C. Grainger, W. J. Wales, N. Linden, M. Porker, and B. J. Hayes. 2011. Variation in residual feed intake in Holstein-Friesian dairy heifers in southern Australia. J. Dairy Sci. 94:4715-4725.

Xi, Y. M., F. Wu, D. Q. Zhao, Z. Yang, L. Li, Z. Y. Han, and G. L. Wang. 2016. Biological mechanisms related to differences in residual feed intake in dairy cows. Animal 10:1311-1318.

Zamani, P., S. R. Miraei-Ashtiani, D. Alipour, H. Aliarabi, and A. A. Saki. 2011. Genetic parameters of protein efficiency and its relationships with yield traits in lactating dairy cows. Livest. Sci. 138:272-277.

Zetouni, L., M. Henryon, M. Kargo, and J. Lassen. 2017. Direct multitrait selection realizes the highest genetic response for ratio traits. J. Anim. Sci. 95:1921-1925.

\section{ORCIDS}

E. Liu (ㄴ) https://orcid.org/0000-0001-8608-9074

M. J. VandeHaar ๑ https://orcid.org/0000-0002-8475-3493 